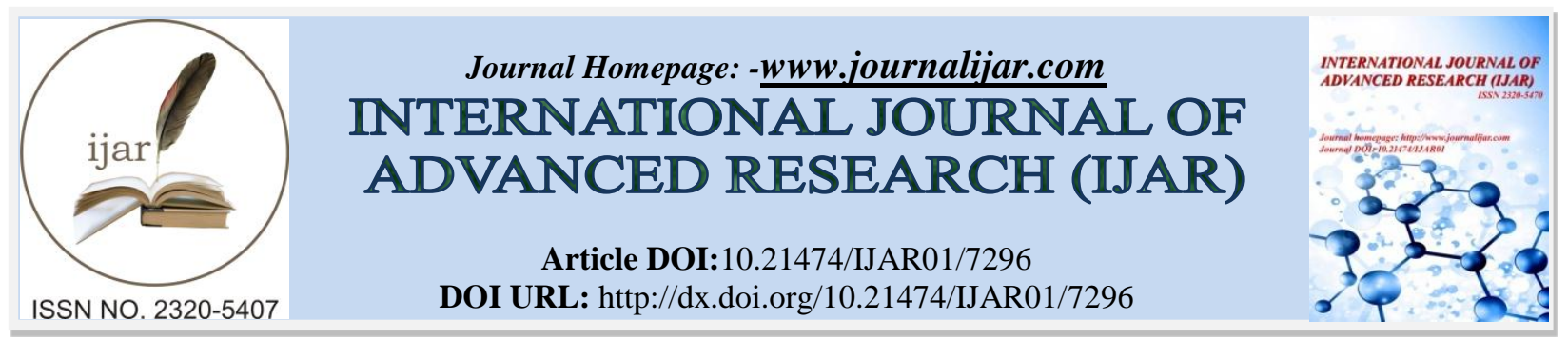

RESEARCH ARTICLE

\title{
ENHANCING STUDENT'S RETENTION OF KNOWLEDGE BY USING DIGESTIVE SYSTEM TEXTBOOK BASED ON PROCESS IMAGES.
}

\author{
Devin Susbandya, Jekti Prihatin, Dwi Wahyuni, Sutarto and Indrawati. \\ Department of Science Education Magister, University of Jember, Jember, Indonesia 68121.
}

\section{Manuscript Info}

Received: 16 April 2018

Final Accepted: 18 May 2018

Published: June 2018

Keywords:-

Textbooks, process images, digestive system, retentions.

\section{Manuscript History}

\begin{abstract}
Textbooks are still one of the main learning media which used in the Biology learning process. Generally, students are used to using textbooks than digital versions. Basically, Biology is one of the most visual sciences, so it cannot be separated from the use of images. Biology learning is also based on the remembrance and object of Biology mostly consist about various abstract concepts including physiological processes on digestive system material. Most of these physiological processes require suitable media to visualize it. The effort to facilitate students learning process is not only by developing textbooks. However, innovation is also carried out by combining characteristics of images and processes into textbooks. Therefore, it takes a textbook based on process images about the digestive system. Process images are a series of sequential images as a whole, able to describe a particular process, interesting, easy to understand and use. In addition, textbooks based on process images also facilitate students to map information related to concepts, so it can be stored systematically in the brain. Therefore, it will also increase students' learning retention as well as one of the determinants of student learning achievement. This study aims to examine the effectiveness of the use of textbooks based on process images on digestion system material to student' $\mathrm{s}$ retention. The data analyzed were obtained from the value of posttest and retest. Then, the values are analyzed using the Recognition method to find out the criteria of student learning retention.
\end{abstract}

Copy Right, IJAR, 2018,. All rights reserved.

\section{Introduction:-}

A book is still the main learning resource used by teachers on learning process (Tania and Fadiawati, 2015:164). The use of printed textbooks (57.4\%) was more common than the digital version (Millar and Schrier, 2015:174). Textbooks were also regarded as a reliable medium and able to provide important information that supports and enhances the learning process of students (Knight, 2015:1). However, the existing printed textbooks are generally still not able to facilitate the learning process of students maximally (Tania and Fadiawati, 2015:164). That is because of the content of the book which contains more verbal explanations or words and the lack of use of images that are able to visualize a thing or state related to a concept. Thus, it will affect the success of student learning process from the beginning (when observing activity). 
Basically observing activities as successful determinants of the next stage in observing, questioning, reasoning, trying, and communicating, involved a particular process and assisted with the images, so that students can understand important concepts related to matter (Yusmar et al., 2017:2). Biology is the most visually classified science and has a long history of using images to define and relate concepts in living systems (Bell, 2014:1). Based on the results of the researcher survey, it was known that 18 of 20 students felt more interested in learning to use printed textbooks equipped with many pictures or images. It showed that images can increase students' interest in the subject of Biology, including the material of Digestive System.

In addition, students still had difficulties in understanding some of the physiological concepts of the digestive system, for example, the location of the organ, peristaltic motion, organ working mechanism, and related enzymes (chemical digestion) as well as the absorption process (nutrients and water). Body as a biological system was characterized by organization, interaction, complex components, and a dynamic process (Assaraf et al., 2011:33-34). Most of the physiological processes which occurred in the digestive system were abstract and can't be observed directly.

Overall, basically, Biology learning cannot be separated from images and processes. Thus, innovations that can be done to improve student learning process is to unify the characteristics of the image and process. The process image is defined as an image or modeling that contains a series of different images (size, shape, color, position, position), but one image with the others is a unified whole and describes a particular process (Harianto et al., 2017). Main characteristics of a process image include: composed of several different images (colors, shapes, sizes, positions), the images are arranged in sequence, constituting a unity or interconnected, and describing a particular process. Thus, the concept of a food-digestive process is illustrated by a series of different consecutive images (size, shape, color, position), but remains a unity). Therefore, students can understand and remember important concepts for a long time.

Retention is an ability to remember concepts and theories that have been studied previously in a certain period, so that can determine the results of a learning process. Student retention belongs to a complex system and it required certain efforts and strategies to improve it (Forsman et al., 2014; Forsman et al., 2015). Educators can organize and conditioned learning in schools to increase student retention (McGregor and Mills, 2012), including the use of textbooks based on process images.

Basically, process images include a simplified form of a complicated process being simpler presented through various images, icons, symbols, shapes, diagrams in such a way. The presentation is suitable with the characteristics of the process images. The purpose of simplification is to facilitate the brain in recalling information (Topsakal and Oversby, 2013:28). It relates to the limited capacity of the brain and cannot accommodate the overall complex information at once (Jensen, 2005:43).

Generally, cerebellum consists of two hemispheres: the right hemisphere and the left hemisphere associated with the corpus callosum (Jensen, 2005; Campbell, 2008). The left hemisphere plays a role in verbal or linguistic, logic, numeracy, math, intellectual and consecutive work abilities. The right hemisphere emphasizes related things rhythm, music, images, creativity, and emotional (Long et al., 2012; Corballis, 2014). As for, part of the brain that also plays an important role related to remembering new information is hippocampus.

Hippocampus includes the center of learning and memory (McCrory et al., 2010; Wilson et al., 2011). The majority centers of the short-term memory was on the frontal lobes of the brain (Linden et al., 2003) and information is accessed within the hippocampus link, but when the memory is made into long-term, the link is replaced by a more permanent connection within the cerebral cortex (the gray-ash outside of each hemisphere) (Jensen, 2005:16; Campbell, 2008). The use of printed textbooks based on process images can facilitate students to map information from various concepts and theories about a material so that it can be stored systematically in the brain. A display can be an image of a particular object can visualize the condition and character of the object, while affecting the perception of the object (Stefanikova and Prokop, 2015). In addition, the use of images that have been developed in such a way could enhance the integration of information in a text (Dunlosky et al., 2013), made it easy to understand and remember the information. Thus, the use of appropriate media (easy to use, communicative and informative) includes solutions that can be done to overcome the problems that generally occur in the learning process (Syahroni et al., 2016:117) such as student's retention of knowledge. One of the media that can be used is printed textbooks based on process images to solve the problem, especially about the digestive system. Therefore, this research aims to 
analyze the effectiveness of printed textbooks based on process images in improving students' learning retention about the digestive system.

\section{Research Method:-}

The initial stage of this research is a trial use of textbooks based on process image on the digestive system material which is done in a cyclic manner. The subjects of product trial are students of the eleventh class of senior high school 02 Bondowoso, Indonesia (class A) and senior high school 01 Prajekan, Bondowoso, Indonesia (class B). Each trial is conducted during four meetings and use products that have been validated by experts (materials, media, and development).

Student's retention of knowledge is derived from posttest and retest results. The posttest is given after the last meeting, while the retest takes 2 weeks after the posttest. Then the value is analyzed using recognition method to determine the criteria of student learning retention score (formula 1). The score criteria obtained from the calculation will be interpreted according to the criteria in Table 1.

$$
R=\frac{\text { Retest }}{\text { Posttest }} \times 100 \%
$$

Table 1:-The criteria of student's learning retention

\begin{tabular}{|c|c|}
\hline Retention (\%) & Qualitative Criteria \\
\hline $\mathrm{R}<50$ & Very Less \\
\hline $50 \leq \mathrm{R}<60$ & Less \\
\hline $60 \leq \mathrm{R}<70$ & Enough \\
\hline $70 \leq \mathrm{R}<80$ & Good \\
\hline $\mathrm{R} \geq 80$ & Very Well \\
\hline
\end{tabular}

(Source: Roediger and Karpicke, 2006).

\section{Findings and Discussion:-}

The results of product trials which mainly related to student learning retention involve posttest and retest result. The mean of test results for each trial (A and B) are presented in Table 2. and Figure 1.

Tabel 2:-The mean of student's posttest and retest

\begin{tabular}{|l|c|c|c|c|}
\hline \multirow{2}{*}{ Test } & \multicolumn{2}{c|}{ Class A } & \multicolumn{2}{c|}{ Class B } \\
\cline { 2 - 5 } & N & Mean & N & 79 \\
\hline Posttest & 40 & 82.9 & 30 & 79.4 \\
\hline Retest & 40 & 80.6 & 30 & 77.6 \\
\hline
\end{tabular}

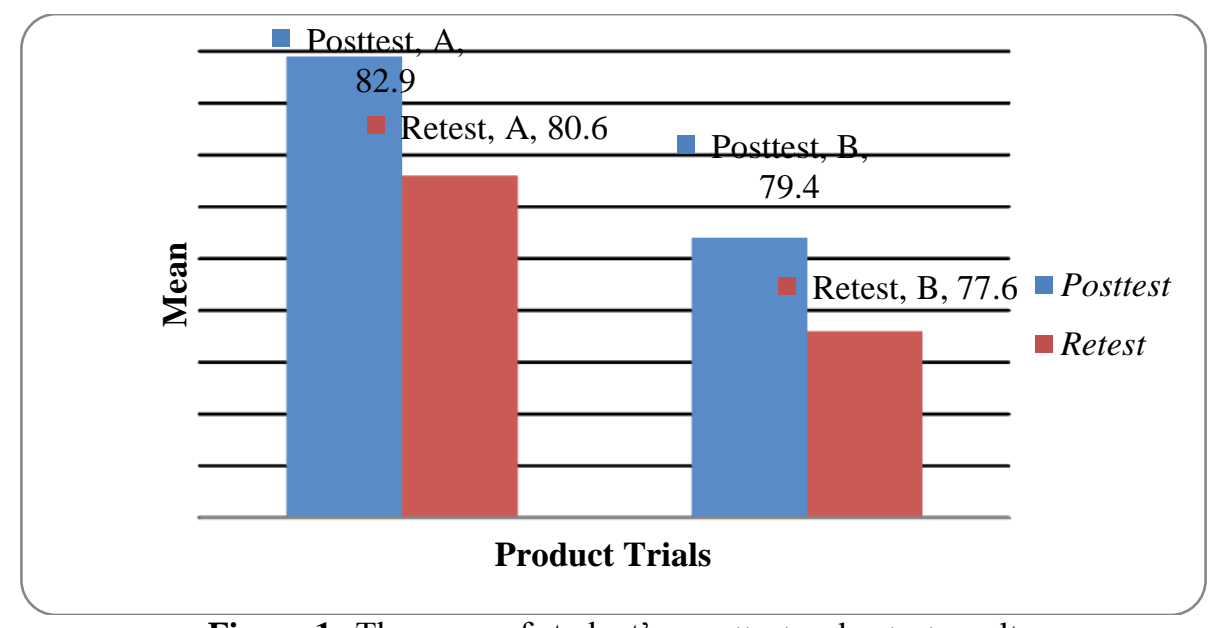

Figure 1:-The mean of student's posttest and retest result 
The information in Table 2. and Figure 1. shows the students' retention of knowledge of the material slightly decreased after 2 weeks. This is indicated by the mean of retest $80.6(\mathrm{~A})$ and $77.6(\mathrm{~B})$. The result is smaller than the mean of posttest, but it is still above the minimum exhaustiveness criteria. Furthermore, criteria of students' retention can be seen in Table 3 .

Table 3:-The result of percentage calculation of student retention

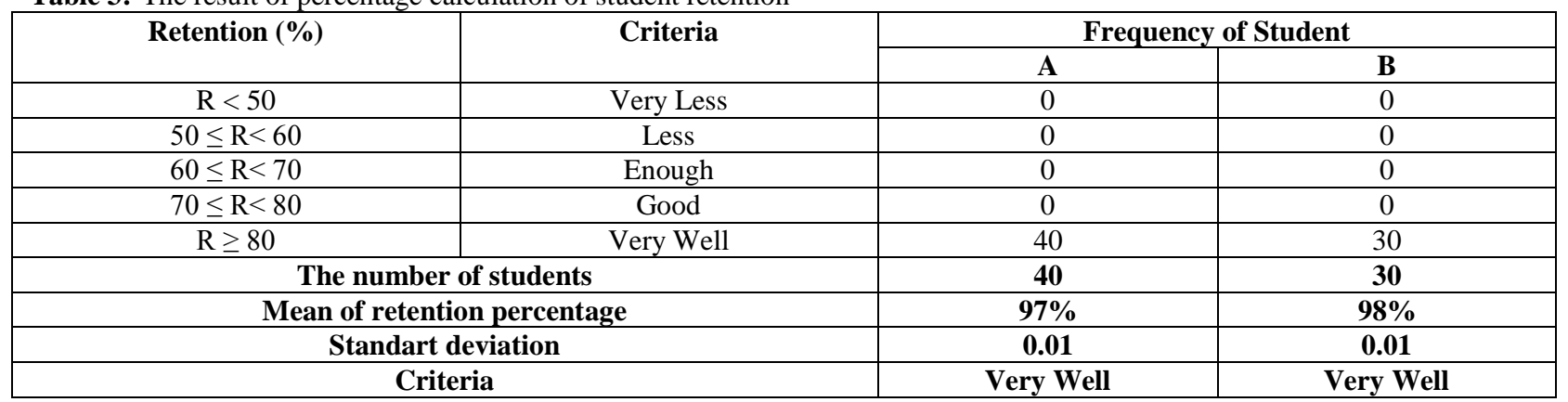

Based on Table 3, it can be seen that criteria of students' retention about digestion system is very well with the mean of percentage $97 \%$ (A) and 98\% (B). The results are obtained from the calculation of posttest and retest value of each student using the formula that has been determined (Formula 1). In addition, the retention percentage of each student is almost no difference. This is shown by the very small standard deviation (0.01).

\section{Discussion:-}

Visualization of concepts related to the process of food digestion includes the main advantages of digestive system textbooks based on process images which are different than other textbooks. Based on Table 2, it is known that textbooks based on process images can also improve students' understanding and memory in both trials (A and B). This is shown from the good mean value. In addition, retest result is less than posttest because it indicates a conceptrelated memory reduction after an interval of 2 weeks. However, based on the results in Table 3. the description materials based on process images can minimize the occurrence of forgetting or in other words can be easier to remember the concept has been studied, so it fulfills the very well criteria of retention. The information presented through the images also lingers longer than just words (Bransford et al., 2005: 124; Rinne et al., 2011:89-90; Hardiman et al., 2014:144). It because of the information is more memorable and has a greater possibility to be stored in long-term memory. The possibility is also related to the processing of information in Dual Coding Theory, between verbal and non-verbal. Nevertheless, the presentation of the materials in textbooks based on process images also includes verbal explanations. The combination of the use of verbal and nonverbal media can improve the learning process of students because learning information becomes more easily absorbed by students (Clark and Paivio, 1991).

The use of process images illustration is not only related to the function of the right hemisphere brain but also the left hemisphere. Picture or visual stimulation becomes part of the right hemisphere function (right brain), whereas the left brain is more likely to be verbal stimulation. Basically, the characteristics of the process images also show the existence of the relationship with the left hemisphere brain function that is related to the process gradual and sequential. Thus, the use of process images in learning can also maximize the function of both students' hemispheres. This is due to the mutual cooperation between the right and left hemispheres in performing their functions (Gulpinar, 2005:301; Gainotti, 2014). The thick band of the axon (corpus callosum) allows communication between right and left hemispheres (Jensen, 2005:13, Campbell, 2008) and contributes to other processes including higher cognitive abilities (McCrory et al., 2010; Wilson et al ., 2011).

\section{Conclusion:-}

Based on the results and discussions, digestive system textbooks based on process images can improve students' recall ability related concepts that have been studied. This can be seen from the mean of the retention percentage of both trials (A and B) that fulfill very well the criteria. 


\section{References:-}

1. Assaraf, O. B., Dodick, J., and Tripto, J. 2011. High School Students' Understanding of the Human Body System. Res Sci Educ, 43:33-56.

2. Bell, J.C. 2014. Visual Literacy Skills of Students in College-Level Biology: Learning Outcomes Following Digital or Hand-Drawing Activities. The Canadian Journal for the Scholarship of Teaching and Learning, 5(1):1-13.

3. Bransford, J. D., Brown, A. L., and Cocking, R. R. 2005. How People Learn (Brain, Mind, Experience, and School). Washington: National Academy Press.

4. Campbell, N. A. 2008. Biology (Eight Edition Third Volume). San Fransisco: Pearson Benjamin Cummings.

5. Clark, J. M., and Paivio, A. 1991. Dual Coding Theory and Education. Educational Psychology Review, 3(3):149210 .

6. Corballis, M. 2014. Left Brain, Right Brain: Facts and Fantasies. Plos Biology, 12(1):1-6.

7. Dunlosky, J., Rawson,K. A., Marsh, E. J., Nathan, M. J., and Willingham, D. T. 2013. Improving Students' Learning with Effective Learning Techniques: Promising Directions from Cognitive and Educational Psychology. Psychological Science in the Public Interest, 14(1):4-58.

8. Forsman, J., Bogaard, M. V., Linder, C., and Fraser, D. 2015. Considering Student Retention as a Complex System: a Possible Way Forward for Enhancing Student Retention. European Journal of Engineering Education, 40(3):235255.

9. Forsman, J., Linder, C., Moll, R., Fraser, D., and S. Andersson. 2014. A New Approach to Modelling Student Retention Through an Application of Complexity Thinking. Studies in Higher Education, 39(1):68-86.

10. Gainotti, G. 2014. Why Are the Right and Left Hemisphere Conceptual Representations Different?. Behavioural Neurology, 2014:1-10.

11. Gulpinar, M.A. 2005. The Principles of Brain-Based Learning and Constructivist Models in Education. Educational Sciences: Theory \& Practice, 5 (2):299-306.

12. Hardiman, M., Rinne, L., and Yarmolinskaya, J. 2015. The Effects of Arts Integration on Long-term Retention of Academic Content. Mind, Brain, and Education, 8(3):144-148.

13. Harianto, R., Harimukti, A., Sutarto, and Indrawati, 2017. Development of Module Based on Process Image for Learning of Circular Motion in Senior High School. Educational Steady Stream Journal, Jember University, 6(4):1722.

14. Jensen, E. 2005. Teaching with The Brain in Mind (Second Edition). Alexandria: Association for Supervision and Curriculum Development.

15. Knight, B. A. 2015. Teachers' Use of Textbooks in the Digital Age. Cogent Education, 2:1-10.

16. Long, D. L., Johns, C. L., and Jonathan, E. 2012. Hemispheric Differences in the Organization of Memory for Text Ideas. Brain \& Language, 123 (2012):145-153.

17. McCrory, E., De Brito, S. A., and Viding, E. 2010. Research review: The Neurobiology and Genetics of Maltreatment and Adversity. Journal of Psychology and Psychiatry, 51, 1079-1095.

18. McGregor, G., and Mills, M. 2012. Alternative Education Sites and Marginalised Young People: I Wish There were More Schools like this One. International Journal of Inclusive Education, 16(8):843-862.

19. Millar, M and Schrier, T. 2015. Digital or Printed Textbooks: Which do Students Prefer and Why?. Journal of Teaching in Travel \& Tourism, 15:166-185.

20. Rinne, L., Gregory, E., Yarmolinskaya, J., and Hardiman, M. 2011. Why Arts Integration Improves Long-term Retention of Content. Mind, Brain, and Education, 5(2):89-96.

21. Roediger, H. L., and Karpicke, J. D. 2006. Test-Enhanced Learning: Taking Memory Tests Improves Long-Term Retention. Psychological Science, 17(3):249-255.

22. Stefanikova, S., dan Prokop, P. 2015. Do We Believe Pictures More or Spoken Words? How Specific Information Affects How Students Learn about Animals. Eurasia Journal of Mathematics, Science \& Technology Education, 11(4):725-733.

23. Syahroni, M. W., Dewi, N. R., and Kasmui. 2016. The Effect of Using Digimon (Science Digital Module) with Scientific Approach at the Visualization of Students' Independence and Learning Results. Jurnal Pendidikan IPA Indonesia, 5(1):116-122.

24. Tania, L., and Fadiawati, N. 2015. The Development of Interactive E-Book based Chemistry Representations referred to the Curriculum of 2013. Jurnal Pendidikan IPA Indonesia. (2):164-169.

25. Topsakal, U. U., and Oversby, J. 2013. What do Scientist and Non-scientist Teachers Notice about Biology Diagrams?. Journal of Biological Education, 47(1):21-28.

26. Wilson, K. R., Hansen, D. J., and Li, M. 2011. The Traumatic Stress Response in Child Maltreatment and Resultant Neuropsychological Effects. Aggression and Violent Behavior, 16(2):87-97.

27. Yusmar, F., Susbandya, D., Widita, E. V., Maghfiroh, L., Prihatin, J., and Sutarto. 2017. A Concept: Enhancing Biologi Learning Quality by Using Process Image. Educational Steady Stream Journal, Jember University, 6 (2):111. 